\title{
PERANAN KEPALA DESA MUARA SUNGAI DALAM PENGELOLAAN PASAR
}

\section{THE ROLE OF THE HEAD OF MUARA SUNGAI VILLAGE IN THE MANAGEMENT OF THE MARKET}

\author{
Yelli Aswariningsih \\ Sekolah Tinggi Ilmu Ekonomi (STIE) Prabumulih \\ e-mailyelli@ ac.id
}

\begin{abstract}
Village planning provides the flexibility and opportunity for villages to explore local initiatives (ideas, desires and local will) which are then institutionalized into policies, programs and activities in the field of village governance and development. The purpose of the study was to explain the role of the village head in the management of the Muara Sungai village market in the management of the village market in the Muara river village, CambaiPrabumulih Timur District. The research method is descriptiveanalytical with the juridical-empirical method. The results showed that the role of Muara Sungai village head Cambai Subdistrict, Prabumulih Timur Regency in issuing a policy in village market management had not been done properly and correctly, this proved the village head could not issue a form of policy according to his authority, so that it did not provide benefits and income to the village treasury. This is seen as unproductive due to unclear management patterns. So in essence the village market has not provided benefits to increase village income. Therefore, the management of village markets should be improved through standardized management mechanisms and systems as well as accountability in order to avoid irregularities.
\end{abstract}

Keywords : Management, Market, Village, Village Head

\begin{abstract}
ABSTRAK
Perencanaan desa memberikan keleluasaan dan kesempatan bagi desa untuk menggali inisiatif local (gagasan, kehendak dan kemauan lokal) yang kemudian dilembagakan menjadi kebijakan, program dan kegiatan dalam bidang pemerintahan dan pembangunan desa. Tujuan penelitian untuk menjelaskan peranan kepala desa dalam pengelolaan pasar Desa Muara sungai dalam pengelolaan pasar desa di Desa Muara sungai Kecamatan CambaiPrabumulih Timur. Metode penelitian bersifat deskriptifanalitis dengan metode yuridis-empiris. Hasil penelitian menunjukkan bahwa peranan Kepala Desa Muara sungai Kecamatan Cambai Kabupaten Prabumulih Timur dalam mengeluarkan suatu kebijakan dalam pengurusan pasar desa belum dilakukan secara baik dan benar, hal ini terbukti kepala desa belum bisa mengeluarkan suatu bentuk kebijakan sesuai kewenangannya, sehingga tidak memberikan keuntungan dan pemasukan ke kas desa. Hal ini dipandang tidak produktif akibat pola pengelolaan yang kurang jelas. Jadi pada intinya pasar desa belum memberi manfaat terhadap peningkatan pendapatan desa. Oleh sebab itu, pengelolaan pasar desa hendaknya disempurnakan melalui mekanisme dan sistem pengelolaan yang baku serta pertanggungjawaban agar tidak terjadi penyimpangan.
\end{abstract}

Keywords : Manajemen, Pasar, Desa, Kepala Desa 


\section{PENDAHULUAN}

Pasal 18 ayat (1) Undang-Undang Dasar Negara Republik Indonesia menyatakan "Negara Kesatuan Republik Indonesia dibagi atas daerahdaerah provinsi, dan provinsi itu dibagi atas kabupaten dan kota, yang tiap-tiap provinsi, kabupaten dan kota itu mempunyai pemerintahan daerah yang diatur dengan undang-undang". Pelaksanaan pasal tersebut diatur dalam Undang-Undang Nomor 23 Tahun 2014 tentang Pemerintahan Daerah dan untuk konteks desa diatur dalam UndangUndang Nomor 6 Tahun 2014 tentang Desa.

Pengertian dan pemahaman orang tentang desa dan pedesaan berbeda antara satu daerah dengan daerah yang lain pada awalnya merupakan organisasi komunitas lokal yang mempunyai batas-batas wilayah, dihuni oleh sejumlah penduduk, dan mempunyai adat-istiadat untuk mengelola dirinya sendiri.1 Hazairin memberikan uraian mengenai masyarakat hukum adat, sebagai "Masyarakat-masyarakat hukum adat seperti desa di Jawa, marga di Sumatera Selatan, nagari di Minangkabau, huria di Tapanuli, wanua di Sulawesi Selatan adalah kesatuankesatuan kemasyarakatan yang mempunyai kelengkapan-kelengkapan untuk sanggup berdiri sendiri, yaitu mempunyai kesatuan hukum, kesatuan penguasa dan kesatuan lingkungan hidup berdasarkan hak bersama atas tanah dan air bagi semua anggotanya..." (Soekanto 1992).

Ketentuan Pasal 19 UndangUndang Nomor 6 Tahun 2014 tentang Desa Kewenangan Desa, meliputi: 1) kewenangan berdasarkan hak asal usul; 2) kewenangan lokal berskala desa; 3) kewenangan yang ditugaskan oleh pemerintah, pemerintah daerah provinsi, atau pemerintah daerah kabupaten/kota; 4) kewenangan lain yang ditugaskan oleh pemerintah, pemerintah daerah provinsi, atau pemerintah daerah kabupaten/kota sesuai dengan ketentuan peraturan perundang- undangan; 5) kewenangan lokal berskala desa paling sedikit terdiri atas kewenangan: 6) pengelolaan tambatan perahu; 7) pengelolaan pasar desa; 8) pengelolaan tempat pemandian umum; 9) pengelolaan jaringan irigasi; 10) pengelolaan lingkungan pemukiman masyarakat desa, 11) pembinaan kesehatan masyarakat dan pengelolaan pos pelayanan terpadu; 12) pengembangan dan pembinaan sanggar seni dan belajar; 13) pengelolaan perpustakaan desa dan taman bacaan; 14) pengelolaan embung desa; 15) pengelolaan air minum berskala desa; 16) pembuatan jalan desa antar pemukiman ke wilayah pertanian.

Berdasarkan kewenangan tersebut maka desa mempunyai kesempatan dan tanggung jawab mengatur rumah tangganya sendiri untuk kepentingan masyarakat setempat sekaligus dapat membuat perencanaan lokal. Perencanaan desa akan memberikan keleluasaan dan kesempatan bagi desa untuk menggali inisiatif local (gagasan, kehendak dan kemauan lokal) yang kemudian dilembagakan menjadi kebijakan, program dan kegiatan dalam bidang pemerintahan dan pembangunan desa. Kewenangan berskala desa menghendaki peranan kepala desa untuk lebih maksimal dalam mengelola kewenangannya dalam rangka kemajuan desa.

Pengelolaan merupakan terjemahan dari kata "management". Secara etimologi management yang diterjemahkan menjadi manajemen berasal dari kata "manus" yang berarti tangan dan kata "agree" yang berarti melakukan yang setelah digabung menjadi kata "manage" berarti mengurus atau "managiere" dari bahasa latin berarti melatih. Manajemen dapat diartikan merupakan suatu proses mengatur untuk mewujudkan tujuan yang diinginkan melalui fungsifungsinya antara lain planning, organising, actuating, dan controlling (Syafiie, 2008). 
Menurut Suharsimi, pengelolaan berarti suatu tindakan yang dimulai dari penyusunan data, merencana, mengorganisasikan, melaksanakan, sampai dengan pengawasan dan penilaian. Pengelolaan akan menghasilkan sesuatu, dan sesuatu itu dapat merupakan bentuk sumber penyempurnaan dan peningkatan pengelolaan terhadap rencana selanjutnya. Pengelolaan lokal berskala desa sebagaimana telah disinggung, salah satunya seperti pasar desa setidaknya dapat memperhatikan asasasas pengelolaan seperti dikemukakan Dhani Nasution, diantaranya:

1. Asas fungsional, yaitu pengambilan keputusan dan pemecahan masalah di bidang pengelolaan barang oleh kuasa pengguna barang, pengelola barang sesuai fungsi, wewenang dan tanggung jawab masingmasing.

2. Asas kepastian hukum, yaitu pengelolaan barang harus dilaksanakan berdasarkan hukum dan peraturan perundang-undangan.

3. Asas transparansi, yaitu penyelenggaraan pengelolaan barang milik harus transparan terhadap hak masyarakat dalam memperoleh informasi yang benar.

4. Asas efisiensi, yaitu pengelolaan barang diarahkan agar barang digunakan sesuai batasan-batasan standar kebutuhan yang diperlukan dalam rangka menunjang penyelenggaraan tugas pokok dan fungsi pemerintahan secara optimal.

5. Asas akuntabilitas, yaitu pengelolaan barang harus dapat dipertanggungjawabkan kepada rakyat.

6. Asas kepastian nilai, yaitu pengelolaan barang harus didukung oleh adanya ketepatan jumlah dan nilai barang dalam rangka optimalisasi pemanfaatan dan pemindahtanganan barang serta penyusunan neraca pemerintah.
Asas-asas pengelolaan asset diterapkan sebagai bentuk manajemen pemerintah yang mengacu pada prinsipprinsip good governance. Asas pemerintahan yang baik dapat dilihat dari 3 (tiga) aspek, yaitu teori, normatif dan praktik. Pengelolaan lokal berskala desa, seperti pasar desa di Desa Muara Sungai ,Kecamatan Cambai , Kabupaten Prabumulih timur dalam pengamatan penulis belum memberikan konstribusi yang maksimal. Padahal menurut kepala desa berwenang sepenuhnya mengelola pasar desa sebagai bagian untuk meningkatkan pendapatan asli desa. Untuk itu, penulis tertarik meneliti peranan kepala desa tersebut dalam pengelolaan pasar desa.

Penelitian ini belum pernah diteliti sebelumnya, meskipun pernah penulis lain mengangkat permasalahan desa, namun lokasi dan substansinya berbeda dengan penelitian ini, seperti Sarpin pernah menulis tentang peran kepala desa dalam pembangunan desa studi di Desa Genjor, Kecamatan Sugihwaras, Kabupaten Bojo- negoro. Dalam penelitiannya menyimpulkan peran desa dalam melakukan penyuluhan rencana pembangunan desa melalui gagasan kepala desa. Kepala desa merupakan motivator, inisiator, dan fasilitator dalam kegiatan pembangunan desa.

Hendrik menulis peran kepala desa dalam penyelenggaraan pembangunan Desa Tanjung Keranjang, Kecamatan Malinau, Kota Kabupaten Malinau. Ia menjelaskan faktor penghambat dalam melaksanakan tugas sebagai peran kepala desa karena kurangnya kesadaran masayarakat dalam memberi atau menyumbangkan sesuatu untuk desanya sendiri, baik berupa fisik, dana, maupun pikiran. Terkadang setiap keputusan yang diambil tidak dapat sepenuhnya diterima oleh semua masyarakat yang disebabkan adanya pengaruh-pengaruh dari luar yang menginginkan keputusan tersebut diubah. Sehingga hal ini dapat berpengaruh juga dalam penyelenggaraan pembangunan Desa 
Tanjung Keranjang (Hendrik, 2013).

Saleh dan Hariati pernah meneliti tentang peran kepala desa sebagai administrator pembangunan di Desa Moncongloe, Kecamatan Moncongloe, Kabupaten Maros. Menurutnya peran peran Kepala desa sebagai administrator pembangunan sudah berjalan dengan baik, selaku pemerintah desa sudah menjalankan perannya sebagai motivator, fasilitator, dan mobilisator sesuai dengan tugas, wewenang dan fungsinya sebagai administrator pembangunan desa (Saleh \& Hariati 2016).

Roza dan Arliman meneliti tentang peranan Badan Permusyawatan Desa (BPD) di dalam pembangunan desa dan pengawasan keuangan desa. Dalam penelitiannya disimpulkan bahwa peran BPD memiliki posisi strategis dalam menjawab kebutuhan masyarakat. Perannya sangat besar dalam mempercepat keberhasilan pembangunan desa (Roza \& Arliman 2017).

Hermansyah, peran kepala desa dalam pelaksanaan pembangunan Kecamatan Tana Lia, Kabupaten Tana Tidung studi kasus di Desa Tanah Merah dan Desa Sambungan. Penulis menyimpulkan Peran kepala desa dalam pelaksanaan pembangunan di Desa Tanah Merah dan Desa Sambungan dapat dilihat dari peran kepala desa sebagai motivator, pendorong, penggerak atau seseorang yang memberikan motivasi untuk mencapai suatu tujuan agar pelaksanaan pembangunan berjalan sesuai dengan yang diharapkan. Berdasarkan dari hasil penelitian dan pembahasannya disebutkan bahwa Kepala Desa Tanah Merah telah menjalankan tugas dan fungsinya serta perannya sebagai seorang motivator (Hermansyah 2015) Musfianawati, pernah menulis tentang peran kepala desa dalam mewujudkan kesejahteraan masyarakat miskin melalui peraturan desa.

Hasil penelitianya menjelaskan peraturan desa merupakan peraturan yang disusun oleh kepala desa bersama badan permusyawaran desa melalui hasil dari masukan-masukan dari lembaga kemasyarakat maupun tokoh dan masyarakat yang ada di desa. Peraturan desa disusun mengenai pembangunan jangka menengah desa, rencana kerja pemerintah desa, anggaran pendapatan belanja desa dan laporan pertanggungjawaban realisasi pelaksanaan anggaran pendapatan belanja desa (Musfinawati, 2015).

Kemudian hal lain yang belum diatur dalam tata urutan perundangundangan. Dalam mewujudkan desa yang mandiri dan berdaulat untuk kesejahteraan seluruh masyarakat terkait dengan terpenuhinya kebutuhan dasar masyarakat maka semestinya seorang kepala desa yang mempunyai kekuasaan penuh di desa adalah seorang yang bertakwa, orang yang amanah, terpercaya dan orang yang peduli kepada sesame manusia. Kesejahteraan masyarakat di desa tergantung semua pada sosok siapa kepala desanya.

\section{METODE PENELITIAN}

Penelitian ini dilaksanakan di Desa Muara sungai , Kecamatan cambai, KabupatenPrabumulih timur . Pendekatan penelitian bersifat deskriptif-analitis dengan metode yuridis-empiris. Sumber data dalam penelitian ini terdiri atas data primer dan data sekunder. Pengambilan data primer dilakukan dengan cara wawancara, sedangkan data sekunder dilakukan dengan cara studi kepustakaan. Data dalam penelitian ini kemudian diinventarisir lalu dipilih yang relevan, kemudian dianalisis dengan menggunakan metode deskriptif kualitatif.

\section{HASIL DAN PEMBAHASAN}

Peranan Kepala Desa Muara Sungai dalam Pengelolaan Pasar Desa Muara Sungai Kecamatan Cambai. Kabupaten Prabumulih Timur. Desa dengan hak otonomnya berhak mengelola keuangan desa secara 
mandiri, baik mengelola pendapatan dan sumber-sumber pendapatan maupun mengelola pembelanjaan anggaran tersebut. Akan tetapi, pada kenyataannya sangat banyak desa-desa yang belum dapat memanfaatkan keistimewaannya. Desa-desa tersebut sebagian besar hanya mengelola aset desa (pasar desa) untuk pendapatan desa kepada siapa yang mau mengerjakannya. Sesuai yang dinyatakan dalam Pasal 26 UndangUndang Nomor 6 Tahun 2014 tentang Desa ayat (1) dan (2) menyebutkan tentang tugas dan wewenang kepala desa, salah satunya memegang kekuasaan pengelolaan keuangan dan aset desa. Hal ini dijelaskan lagi dalam Pasal 34 Peraturan Pemerintah Nomor 43 Tahun 2014 tentang Peraturan Pelaksanaan Undang-Undang Nomor 6 Tahun 2014 tentang Desa yang menyatakan bahwa kewenangan lokal desa berskala desa adalah dalam pengelolaan pasar desa.

Desa mempunyai otonomi dan kewenangan dalam hal perencanaan, pelayanan publik, keuangan Anggaran Pendapatan dan Belanja Desa (APBDes) dan lain-lain. Selain itu, juga mempunyai sistem demokrasi lokal. Artinya, dengan kewenangan pengelolaan pasar desa berdasarkan Undang-Undang Nomor 6 Tahun 2014 tentang Desa dan Peraturan Menteri Dalam Negeri Nomor 1 Tahun 2016 tentang Pengelolaan Aset Desa maka diharapkan desa semakin maju dan makmur.

Kemudian diharapkan keterlibatan aktif masyarakat mulai dari tahap musyawarah perencanaan pengembangan (Musrenbang) desa, pelaksanaan dan pengawasan pembangunan hingga pertangungjawabannya. Namun, kapasitas perangkat desa kurang memahami peraturan perundangan-undangan yang dapat memberikan keuntungan aset desa. Sumber pendapatan asli desa terdiri dari hasil usaha desa, hasil kekayaan desa, hasil swadaya, partisipasi, hasil gotong royong, dan lain-lain.

Pendapatan asli desa diharapkan dapat meningkatkan peran serta masyarakat, mendorong desa lebih bersikap mandiri karena memiliki kewenangan penuh untuk mengurus dan mengontrol desanya sendiri. Kemandirian tersebut, bias menciptakan pertumbuhan ekonomi lebih baik, termasuk pengelolaan aset desa (pasar desa) secara profesional dan bermanfaat langsung pada masyarakat. Kemandirian desa memberikan kewenangan yang luas memaju kinerja perangkat desa dalam memberdayakan warga desanya. Dengan adanya otonomi desa maka otomatis desa akan lebih kreatif dalam menggali penerimaan pendapatan desanya.

Desa Muara Sungai sampai saat sekarang belum dapat mengoptimalkan sumber-sumber pendapatan desa yang berbasis pada aset desa (pasar desa), karena pelaksanaannya masih dikelola oleh Pemerintah Daerah Kabupaten Cambai dalam hal ini Dinas Perindustrian dan Perdagangan. Hasil pengelolaannya tetap diberikan $41 \%$ ke desa. Tidak semua desa di Kecamatan Cambai berbuat lebih kreatif. Dalam menyelenggarakan pemerintahan desa selama ini belum dikelola secara baik mulai dari perencanaan, pelaksanaan sampai ada pengawasannya. Akibatnya, sulit diketahui jumlah sumber pendapatan dan keuangan desa serta pembangunan apa yang telah dilaksanakan.

Pengelolaan yang kurang baik tersebut disebabkan rendahnya pemahaman aturan yang berlaku. Bertolak dari hal itu, semenjak berlakunya Undang-Undang Nomor 6 Tahun 2014 tentang Desa, bagi desa yang diberi hak menyelenggarakan rumah tangganya sendiri diharuskan setiap tahun anggaran menyesuaikan penerimaan dan pengeluaran keuangan desa dengan tahunan anggaran negara. Penggunaan pasar desa yang menjadi sumber pendapatan desa secara kolektif 
banyak dikelola oleh masyarakat yang berada pada desa itu sendiri. Jenis-jenis aset desa di Desa Muara sungai Kecamatan Cambai Kabupaten Prabumulih Timur, terdiri dari: 1) pasar desa; 2) tanah kas desa; dan 3) bangunan desa

Peranan kepala desa dalam pengelolaan pasar desa Muara Sungai semestinya berpedoman pada Peraturan Menteri Dalam Negeri Nomor 1 Tahun 2016 tentang Pengelolaan Aset Desa. Hal tersebut dapat dilihat aspek perencanaan, pengadaan, dan penggunaan.

1. Perencanaan. Proses perencanaan harus melibatkan stakeholder di desa, bertujuan agar pembangunan bersentuhan langsung dengan masyarakat, terlebih dahulu dilakukan dengan cara musyawarah desa. Oleh karena itu, tahap awal perencanaan pengelolaan aset desa harus melalui musyawarah desa. Selanjutnya, dilakukan pengalokasian anggaran yang diperlukan. Setelah musyawarah desa, pemerintah desa melakukan penyortiran terhadap perencanaan jangka pendek maupun jangka panjang. Perencanaan tersebut bersifat sederhana, berarti bahwa susunan rencana tersebut harus sistematis, prioritas, dan semua kegiatan pokok sudah tercakup. Pelaksanaannya berdasarkan asas kepentingan umum, fungsional, kepastian hukum, keterbukaan, efisiensi, efektifitas, akuntabilitas, dan kepastian nilai ekonomi. Hal yang tertuang dalam Rencana Kerja Pemerintah Desa (RKPDes) adalah menyajikan dokumen perencanaan pembangunan tahunan desa sesuai dengan kebutuhan desa. Sesuai dengan Undang-Undang Nomor 6 Tahun 2014 tentang Desa setiap desa wajib menyusun RKPDes.

2. Pengadaan. Menurut Pasal 9 Peraturan Menteri Dalam Negeri Nomor 1 Tahun 2016 tentang Pengelolaan Aset Desa:
Pengadaan aset desa sebagaimana dimaksud dalam Pasal 7 huruf b, dilaksanakan berdasarkan prinsipprinsip efisien, efektif, transparan dan terbuka, bersaing, adil/tidak diskriminatif dan akuntabel. (2) Pengadaan barang/jasa di desa diatur dengan peraturan bupati/walikota dengan berpedoman pada ketentuan peraturan perundang-undangan.

Terkait pengadaan ini menurut Sekretaris Desa Muara sungai bahwa aset yang dimiliki Desa Muara sungai terdiri dari pasar desa, tanah kas desa, pasar hewan dan bangunan desa. Pengelolaan aset desa tersebut tidak seluruhnya ditindaklanjuti dengan pembuatan peraturan desa dan keputusan kepala desa, seperti pasar desa karena masih dikelola oleh pemerintah kabupaten.

3. Penggunaan. Ketentuan Pasal 10 Peraturan Menteri Dalam Negeri Nomor 1 Tahun 2016 tentang Pengelolaan Aset Desa menentukan: a) penggunaan aset desa sebagaimana dimaksud dalam Pasal 7 huruf c, ditetapkan dalam rangka mendukung penyelenggaraan pemerintahan desa, b) status penggunaan aset desa ditetapkan setiap tahun dengan keputusan kepala desa.

Mengenai pendapatan dari pengelolaan pasar desa sudah ditentukan oleh pemerintah kabupaten, yaitu untuk desa hanya diberi $41 \%$, sedangkan $59 \%$ untuk pemerintah kabupaten. Sebagaimana disampaikan Sekretaris Desa Muara sungai bahwa pembagian itu sudah berlangsung sejak tahun 2007 sampai sekarang. Tetapi, hasil yang didapatkan untuk kas desa tidak mengalami penambahan signifikan karena pasar beberapa kali mengalami perbaikan disebabkan roboh dan rusak. Fisik Pasar Desa Muara sungai seluas $2.000 \mathrm{M} 2$ didirikan sejak tahun 1991 terdiri dari beberapa kios dan lapak. Kemudian sejak tahun 2007 Pasar Desa Muara sungai berubah menjadi 2 los dan 16 kios. 
Selanjutnya, semakin berkembang dengan banyaknya lapak yang berubahberubah jumlahnya setiap hari pasar. Berdasarkan penjelasan Sekretaris Desa Muara bahwa kios disewakan $\mathrm{Rp}$ 4.000.000,00 (empat juta rupiah) per tahun, sedangkan lapak disewakan $\mathrm{Rp}$ 1.500.000,00 (satu juta lima ratus ribu) per tahun. Selama berdirinya, pengelolaan Pasar Desa Muara sungai sampai sekarang dikelola oleh pemerintah kabupaten dalam hal ini Dinas Perindustrian dan Perdagangan Kabupaten Cambai. Sewa pengelolaan pasar sebesar $59 \%$ masuk ke kas Pemerintah Daerah Kabupaten Cambai , sisanya $41 \%$ diberikan ke kas Desa Muara sungai . Mulai tahun 2019 diberlakukan retribusi dengan rincian $\mathrm{Rp} 2.000,00$ (dua ribu rupiah) per pedagang dikelola oleh desa dan dijadikan Pendapatan Asli Desa (PAD). Tetapi, dasar penarikan tersebut secara formal belum dikeluarkan oleh Pemerintah Desa MuaraSungai karena tidak ada kewenangan diberikan Pemerintah Kabupaten Prabumulih Timur. Selanjutnya, Sekretaris Desa Muara Sungai mengemukakan bahwa kewajiban pedagang membayar retribusi setiap hari pekan/kalangan dengan rincian sewa petak sebesar Rp $300.000,00$ (tiga ratus ribu) per meter persegi per bulan, untuk los Rp 150.000,00 (seratus lima puluh ribu) per bulan dan retribusi kebersihan sebesar Rp 5.000,00 (lima ribu rupiah) per setiap pedagang. Namun, tidak semua pedagang membayar kewajiban tepat pada waktunya. Pembayaran tergantung dari pendapatan yang mereka terima. Apabila hasil penjualannya mengalami penurunan maka pembayaran tidak tepat pada waktunya.

Penagihan retribusi biasanya dilakukan oleh petugas pengelola pasar setiap bulan, paling lambat setiap tanggal 20 bulan berjalan. Bila terlambat dari waktu yang telah ditentukan maka dikenakan denda $10 \%$ setiap satu bulan dari jumlah yang terutang. Pengelolaan pasar desa di
Kabupaten Prabumulih timur khususnya di Kecamatan Cambai mengacu pada Peraturan Menteri Dalam Negeri Nomor 1 Tahun 2016 tentang Pengelolaan Aset Desa. Sistem pengelolaan hasil Pasar Desa Muara sungai cukup baik, paling tidak mencapai target atau rencana yang ditetapkan karena pedomannya sudah jelas. Hal ini disebabkan pelaporan, penyimpanan, dan penggunaan serta target terpola secara sistematis, sehingga dapat mencegah kepala desa menggunakan secara tidak berdayaguna. Dan sangat diharapkan kepala desa melaporkan hasil Pasar Desa Muara Sungai secara jujur (Sutoro 2008).

Desa yang memiliki pasar desa dapat menyampaikan laporan perkembangan pasar desa dengan ketentuan sebagai berikut.

1. Pengelolaan dan perkembangan pasar desa dilaporkan oleh kades/ lurah kepada camat secara berkala setiap triwulan

2. Camat merekap laporan pasar desa perdesaan/kelurahan untuk selanjut nya dilaporkan kepada wali kota setiap 3 bulan atau 5 bulan berikutnya.

3. Bentuk laporan pengelolaan dan perkembangan pasar desa harus mengacu pada Peraturan Menteri Dalam Negeri Nomor 1 Tahun 2016 tentang Pengelolaan Aset Desa.

Implementasi pengelolaan pasar desa untuk meningkatkan pendapatan desa di KabupatenCambai menurut Kepala Desa Muara sungai tidak berjalan sebagaimana mestinya. Hal ini karena banyak pedagang menunggak membayar sewa pasar desa. Permasalahan pengelolaan pasar desa sangat "disayangkan", mengingat arti penting aset desa tersebut. Menurut Kepala Desa Muara Sungai "pengelolaan pasar desa begitu penting dan mendasar dalam pelaksanaan otonomi desa, sebab hal ini kesempatan bagi desa untuk mendapat hasil yang optimal". Modal inilah yang kemudian harus secara cerdas dan kreatif dapat 
dikelola oleh desa agar kemampuan dalam pembiayaan penyelenggaraan pemerintahan desa, pembangunan, dan kesejahteraan masyarakat dapat diwujudkan. Aturan yang mengatur pasar desa tersebut bisa diperjelas dengan mengkaji ulang aturan yang ada. Menurutnya, keberhasilan optimalisasi pengelolaan pasar desa tidak lepas dari dukungan danpartisipasi semua komponen (stakeholders) baik pemerintahan desa, pemerintah kabupaten, pemerintah provinsi, swasta dan masyarakat, serta adanya faktorfaktor pendukung berupa fasilitasi kegiatan inventarisasi pasar desa, pembinaan melalui penyuluhan kepada kepala desa dan perangkat desa.

Optimalisasi pengelolaan juga dipengaruhi oleh faktor bagaimana pemerintah desa mampu untuk mengevaluasi hasil kerja dalam pengelolaan pasar desa, sekaligus membuat rencana kegiatan baru dalam pengelolaan pasar desa. Kemudian yang tidak kalah penting terkait tawaran dari investor atau pihak ketiga, kepemilikan sumber daya lain terutama sumber daya alam. Menurut anggota BPD Desa M. Sungai kendala internal bersumber dari lembaga pemerintah desa itu sendiri, yaitu dari kepala desa dan perangkat desa. Kendala eksternal disebabkan kurangnya Sumber Daya Manusia (SDM) di kantor Desa Muara sungai.

Kekurangan dimaksud, yaitu staf ahli khusus mengurus pengelolaan aset desa. Saat ini, staf desa yang mengurusi aset desa kurang memahami pengelolaan aset desa yang baik, sehingga berpengaruh terhadap pemanfaatan asset dan kesejahteraan di DesaMuara sungai.Kendala eksternal lainnya disebabkan kurangnya kesadaran dari masyarakat Desa Muara sungai.

Kesadaran dimaksud, seperti gotong-royong tidak lagi hidup di masyarakat, rasa tanggung jawab masyarakat rendah untuk ikut bersamasama meme-lihara aset desa baik yang bergerak maupun yang tidak bergerak.

\section{PENUTUP}

Kesimpulan

Peranan Kepala Desa Muara sungai Kecamatan Cambai Kabupaten Prabumulih timur dalam mengeluarkan suatu kebijakan dalam pengurusan pasar desa belum dilakukan secara baik dan benar, hal ini terbukti kepala desa belum bias mengeluarkan suatu bentuk kebijakan sesuai kewenangannya, sehingga tidak memberikan keuntungan dan pemasukan ke kas desa. Hal ini dipandang tidak produktif akibat pola pengelolaan yang kurang jelas. Akhirnya pasar desa belum memberi manfaat terhadap peningkatan pendapatan desa.

\section{Saran}

1. Pengelolaan pasar desa hendaknya disempurnakan melalui mekanisme dan sistem pengelolaan yang baku serta pertanggungjawaban agar tidak terjadi penyimpangan pengelolaan pasar desa melalui optimalisasi fungsi BPD dalam melakukan pengawasan khususnya pengelolaan pasar desa.

2. Kepala Desa Sungai Muara sungai hendaknya melibatkan partisipasi masyarakat desa secara aktif dan berkesinambungan guna meningkatkan pendapatan asli desa.

\section{DAFTAR PUSTAKA}

Roza, D \& Arliman S. (2017). Peranan Badan Permusyawatan Desa di Dalam Pembangunan Desa dan Pengawasan Keuangan Desa. Jurnal PJIH, 4 (3).

Hermansyah. (2015). Peran Kepala Desa Dalam Pelaksanaan Pembangunan Kecamatan Tana Lia Kabupaten Tana Tidung (Studi Kasus di Desa Tanah Merah dan Desa Sambungan). Journal Pemerintahan Integratif, 3(2).

Syafiie, I, K. (2008). Manajemen Pemerintahan. Jakarta: Perca. 
Musfianawati. (2015). Peran Kepala Desa Dalam Mewujudkan Kesejahteraan Masyarakat Miskin Melalui Peraturan Desa. Jurnal Rechtens, 4 (1).

Hendrik. (2013). Peran Kepala Desa Dalam Penyelenggaraan Pembangunan Desa Tanjung Keranjang Kecamatan Malinau Kota Kabupaten Malinau. Journal Ilmu Pemerintahan, 1(2).

Saleh, S \& Hariati. (2016). Peran Kepala Desa Sebagai Administrator Pembangunan di Desa Moncongloe Kecamatan Moncongloe Kabupaten Maros. Jurnal Office, 2(2).

Soekanto, S. (1992). Hukum Adat Indonesia. Jakarta: Raja Grafindo Persada.

Sutoro, E. (2008). Masa Lalu, Masa Kini dan Masa Depan Otonomi Desa. Yogyakarta: Institute for Research and Empowermen. 